\title{
Upper Crustal Shear-wave Velocity Structure Beneath Western Java, Indonesia from Seismic Ambient Noise Tomography
}

shindy rosalia ( $\square$ shindy.rosalia31@gmail.com )

Institut Teknologi Bandung https://orcid.org/0000-0002-3570-6594

Sri Widiyantoro

Institut Teknologi Bandung

Phil R. Cummins

Australian National University

Tedi Yudistira

Institut Teknologi Bandung

Andri Dian Nugraha

Institut Teknologi Bandung

Zulfakriza Zulfakriza

Institut Teknologi Bandung

Ahmad Setiawan

geological survey of Indonesia

\section{Research Letter}

Keywords: Western Java, Ambient Noise Tomography, Crustal Structure

Posted Date: June 10th, 2021

DOl: https://doi.org/10.21203/rs.3.rs-591913/v1

License: (c) (i) This work is licensed under a Creative Commons Attribution 4.0 International License.

Read Full License

Version of Record: A version of this preprint was published at Geoscience Letters on January 10th, 2022. See the published version at https://doi.org/10.1186/s40562-021-00208-5. 


\section{Abstract}

This paper presents the depth inversion of Rayleigh wave group velocity to obtain an S-wave velocity model from seismic ambient noise cross-correlation in the western part of Java, Indonesia. This study utilizes the vertical component data of a temporary seismograph network deployed in 2016, which was used in a previous study to estimate fundamental mode Rayleigh wave group velocity maps. In this study, the Neighbourhood Algorithm was applied to invert the Rayleigh wave group velocities into 1D shearwave velocity $(V s)$ profiles, which were then interpolated to produce a high-resolution, pseudo-3D $V s$ model. These tomographic images of $V s$ extend to $\sim 20 \mathrm{~km}$ depth and show a pronounced NE-SW contrast of low and high $V s$ in the depth range 1-5 km that correlates well with the Bouguer anomaly map. We interpret the low $V s$ in the northeastern part of the study area as associated with alluvial and volcanic products from the Sunda Shelf and modern volcanic arc, whereas the high $V s$ in the southwestern part is associated with volcanic arc products from earlier episodes of subduction. We also obtained the depth of the northern Java basin, which is in the range of 5-7 km, and the Garut Basin, which extends to $5 \mathrm{~km}$ depth. For greater depths, $V s$ gradually increases throughout western Java, which reflects the crystalline basement.

\section{Introduction}

The island of Java, Indonesia, is part of the Sunda Arc, where the Australian Plate subducts in an almost arc-normal direction beneath the Sunda Block, on the southeastern margin of the Eurasian Plate, with a convergence rate that increases from 58 to $65 \mathrm{~mm} /$ year from west to east (Koulali et al. 2017). The western part of Java, the area of interest in this study, experiences seismicity due to this tectonic activity. Even though no megathrust earthquakes greater than magnitude 8 are known to have occurred offshore Java, several recent subduction zone earthquakes have been large enough to cause damage and/or evacuation of buildings in western Java. These include the 17 July $2006 \mathrm{Mw} 7.7$ Pangandaran tsunami earthquake (Ammon et al. 2006, Fujii \& Satake 2006), the 2 September $2009 \mathrm{Mw} 7.0$ south of Tasikmalaya earthquake (Suardi et al. 2014, Gunawan et al. 2019), the 15 December 2017 Mw 6.5 earthquake near Pangandaran (Sirait et al. 2020), the 23 January 2018 Mw 5.9 offshore Lebak, Banten area (Sirait et al. 2020), and the 2 August 2019 Mw 6.9 on the southern coast of Banten (Fig. 1).

Historically, large earthquakes on crustal faults in western Java have caused widespread damage (Griffin et al. 2019), and the possibility of great $(\mathrm{Mw}>8)$ megathrust earthquakes with long return periods cannot be discounted (Widiyantoro et al., 2020). The potential for such earthquakes to cause much more extensive damage in major urban centers of western Java than have recent earthquakes is therefore of grave concern, especially in light of shallow basin structure that may enhance ground motion there (see Cipta et al. 2018a, b and Pranata et al., 2018, for Jakarta and Bandung, respectively).

Several studies have been conducted to obtain information on the western part of Java subsurface, including body wave tomography studies, e.g., a regional tomographic study using a double-difference method (Rosalia et al. 2019) and a non-linear tomographic study in eastern Sunda Arc using a 
combination of regional and global inversion (Widiyantoro et al. 2011). However, the body wave tomography results have a limitation in shallow depth where there is not enough raypaths coverage due to the earthquake source and station distribution. The limitation makes the upper crust could not be well imaged using body-wave tomography.

More detailed studies in some part of the western part of Java also has been conducted, e.g., in the Jakarta area using ambient noise tomography (Saygin et al. 2016), HVSR method (Cipta et al. 2018a), and microtremor array (Ridwan et al. 2017, 2019); in the Bandung area using ambient noise tomography (Pranata et al. 2020) and seismic microzonation using HVSR method (Pranata et al. 2018). A receiver function method was also applied in the western part of Java using a regional Meteorology, Climatology, and Geophysics Agency (BMKG) network, which gives a 1D velocity model beneath the station (Anggono et al. 2020). The study showed the crustal thickness variation between $25-32 \mathrm{~km}$ in the western part of Java. Even though some studies to obtain the crustal structure information have been conducted in this area, the information of the regional upper crustal velocity structure in a high resolution is limited.

We applied the ambient noise tomography (ANT) method to obtain a regional shallow upper crustal Swave velocity model beneath the western part of Java in higher resolution. In this study, we will focus on the depth inversion of Rayleigh wave group velocity maps from the previous study of Rosalia et al. (2020). From the inferred model, we will better understand the subsurface condition beneath the western part of Java. We also tried to obtain the distribution of the sediment deposit and the depth of the basin in the western part of Java.

\section{Geological Setting}

The subduction margin of the western part of Java is at the transition between oblique subduction in Sumatra to nearly perpendicular subduction south of Java, with the subducting slab dipping at an angle of $60-65^{\circ}$ beneath Java (Hamilton 1979; Malod et al. 1995; Widiyantoro and van der Hilst 1996). Based on physiography, van Bemmelen (1949) divided western Java into three EW-trending zones: the Coastal Plain of Jakarta, and the Bogor, Bandung and Southern Mountain Zones (Fig. 2). Interspersed within the Bogor and Bandung Zones are domes, ridges, depressions and Quaternary volcanoes. The Coastal Plain of Jakarta extends from west to east along the northern coast of western Java. This zone is part of the northern basinal area filled with Eocene-Oligocene non-marine clastic overlain by younger alluvial and volcanic deposits. The Bogor Zone, which lies to the south of the Coastal Plain of Jakarta, consists of Miocene rock layers with igneous intrusions and hilly topography that extends to the west and east around the city of Bogor. The Bandung Zone consists of longitudinal tertiary ridges with depressions filled by volcanic deposits to form the plains of Sukabumi, Bandung, Garut, and Tasikmalaya. The Southern Mountain Zone is a broad regional uplift in southern Java consisting of Pleaogene volcanic arc rocks. The quaternary volcanos of western Java are active andesitic volcanism mostly concentrated in the Bandung Zone (Mt. Tangkuban Perahu, Mt. Patuha, Mt. Guntur, Mt. Galunggung, and Mt. Papandayan). Basement rock underlying the sedimentary rock in the western part of Java is exposed in 
the Ciletuh area, consist of serpentine metamorphic rocks with gabbro dykes, pillow basalt, and volcanic breccia (van Bemmelen 1949; Parkinson et al. 1998; Hall et al. 2007; Clements et al. 2009).

Clements et al. (2009) have interpreted an unconformity in the Ciletuh area as representing of a major thrusting event in the Late Miocene, in which the Southern Mountains were thrust onto the shelf sequences of the southern margin of the Sunda Block. Under this interpretation, the Southern Mountains are the remnant of a volcanic arc that formed in response to subduction of the Australian Plate in the Eocene and Early Miocene, resulting in the formation of a flexural basin between it and the margin of the Sunda Block to the north. After volcanic arc activity shifted northward to its present location, this Paleogene arc was thrust northward $50 \mathrm{~km}$ or more, over the basin and onto the margin of the Sunda Block.

\section{Data And Methods}

Ambient seismic noise has been widely used to study earth structure, using e.g., Ambient Noise Tomography (ANT) and Horizontal-to-Vertical Spectral Ratio (HVSR). Ambient seismic noise used in ANT studies is usually generated by microseisms, resulting from the interaction between ocean waves and the solid earth (Snieder and Wapenaar 2010). Microseisms generate ambient seismic noise at frequencies below $1 \mathrm{~Hz}$, with the primary microseism energy, attributed to topographic coupling between ocean swell and seismic waves on the continental shelf, in the range $0.02-0.1 \mathrm{~Hz}$, while secondary microseisms, attributed to non-linear forcing by ocean swell in both pelagic and coastal regions, is in the range $0.1-1 \mathrm{~Hz}$ (Nishida 2017). It has been shown that cross-correlating the ambient noise recorded simultaneously at a pair of seismographs can yield an estimate of the response of the medium (i.e., a point-source Green's function) that would be measured if there were a source at one of the two seismographs and a receiver at the other (Lobkis and Weaver 2001; Shapiro and Campillo 2004; Snieder and Wapenaar 2010).

Previous studies have shown that ANT can be used to image upper crustal seismic velocity structure in Indonesia, e.g., in Lake Toba (Stankiewicz et al. 2010), ljen Volcano (Spica et al. 2015), Central Java (Zulfakriza et al. 2014), East Java (Martha et al. 2017), Tarutung pull-apart basin, Sumatra Fault (Ryberg et al. 2016), Banda Arc (Porritt et al. 2016), Jakarta (Saygin et al. 2016), Bandung Basin (Pranata et al. 2020), and Agung-Batur Volcano, Bali (Zulfakriza et al. 2020).

Rosalia et al. (2020) utilized a data set collected from 85 temporary broadband seismographic stations deployed in western Java during 2016-2018 (Fig. 2), to estimate interstation Green's functions using cross-correlations of ambient seismic noise. They applied a Trans-dimensional Bayesian approach to estimate fundamental-mode Rayleigh wave group velocity maps from these data in the period range 1$25 \mathrm{~s}$ and showed how these maps correlate with surface geology and centers of volcanic activity. Here we consider the inversion of these 2D group velocity maps to estimate shear velocity $(V s)$ structure as a function of depth in the upper crust. We consider a grid of points regularly distributed throughout the study area, at which the Rayleigh wave group velocity maps define dispersion curves over the frequency range $0.04-1.00 \mathrm{~Hz}$. Each Rayleigh wave group velocity dispersion curves is inverted for a Vs profile over 
0-20 km depth at the respective grid point, and these Vs depth profiles are interpolated between grid points to obtain a pseudo-3D model for Vs structure in the upper crust.

\subsection{Depth Inversion using Neighbourhood Algorithm}

We used the Neighbourhood Algorithm (NA) method to obtain Vs depth profiles at each point in a grid regularly distributed over the study area. The NA method is a Monte-Carlo global direct-search method which uses successive sampling of the model space to assemble an ensemble of models that preferentially samples the low-misfit regions of parameter space (Sambridge 1999a, b).

The NA utilizes a Voronoi cell tessellation if the model space in both a search and appraisal stage. The search stage consists of a direct search in multidimensional parameter space for an ensemble of models that preferentially sample its low-misfit region(s). In this stage, the NA first generates $n_{0}$ models randomly distributed throughout the model-space. A mesh of Voronoi cells, each covering the nearest-neighbour portion of space associated with each model is created. For each model, a theoretical dispersion curve is computed and the misfit between the theoretical and observation curve is assigned to the corresponding cell. Then, $\mathrm{n}_{\mathrm{s}}$ new models are generated within each cell having lowest misfit. A new Voronoi cell tessellation is computed, new misfits are calculated, and the lowest-misfit cells are chosen to resample. This procedure is repeated, and the algorithm stops after a fixed number of iterations. The method results in fine sampling of portions of the model space associated with low misfit, while high-misfit regions are coarsely sampled. The appraisal stage consists of an algorithm for using the entire ensemble of models produced in the search stage to extract information about model uncertainty.

In this study, we produce a series of $V s$ depth profiles using the NA method to invert group velocity dispersion curves constructed from group velocity maps obtained using trans-dimensional tree inversion (Rosalia et al. 2020, Hawkins \& Sambridge, 2015). We grid the study area with intervals of latitude and longitude of $0.1^{\circ}$, producing 557 grid points (Fig. 3a). In each point grid, a dispersion curve is extracted from the 2-D group velocity maps at different periods. Each dispersion curve is then inverted using the Dinver package of Geopsy (Wathelet 2008) to generate a 1-D shear-wave velocity profile at each corresponding grid point. Combining all 1-D Vs profiles from all grid points results in a 3-D model of the subsurface.

In the NA, layered models are selected by choosing parameters from a specific range bounded by a priori minimum and maximum values. The layer parameters used in the surface wave inversion can be described using: S-wave velocity (Vs), thickness (H), P-wave velocity (Vp), and density (Wathelet et al. 2004; Wathelet 2008). The surface waves are less sensitive to Vp and density than to Vs (Takeuchi and Saito 1972; Bache et al. 1978; Tanimoto 1991; Aki and Richards 2002). Therefore, in this study we will just focus on $V s$ structure, by constraining $V p$ and density as descried below.

We parameterize our model based on the CRUST1.0 model (Laske et al. 2013). The CRUST1.0 model is specified on a $1^{\circ} \times 1^{\circ}$ grid and incorporates global estimates of sediment thickness, which is used as the 
guidance to determine the range of depth and velocity parameters. In this inversion, we used three horizontal layers and one half-space layer which is associated with one sediment, two crystalline crustal layers and a half-space, denoted Sediment and Crystalline Crust 1, 2, and 3, respectively, in Tables 1 and 2. Each layer is divided into sublayers that are evenly spaced, with velocities determined by linear interpolation of the velocities at the top and bottom of the layer. The Sediment layer is divided into three sub-layers and the Crystalline Crust 1 and 2 layers are each divided it into five sub-layers. The inversion allows the top and bottom velocities and thickness of each layer to vary.

Table 1

Model Crust 1.0 (Laske et al., 2013) in the western part of Java

\begin{tabular}{|lllll|}
\hline Layer & P-wave $(\mathbf{k m} / \mathbf{s})$ & S-wave $(\mathbf{k m} / \mathbf{s})$ & Density $\left(\mathbf{g} / \mathrm{cm}^{3}\right)$ & Bottom Depth $(\mathbf{k m})$ \\
\hline Sediment & $2.0-3.6$ & $0.6-1.9$ & $1.9-2.3$ & $1.39-4.30$ \\
\hline Crystalline Crust 1 & $5.8-6.0$ & $3.4-3.5$ & $2.6-2.7$ & $8.44-12.15$ \\
\hline Crystalline Crust 2 & $6.3-6.6$ & $3.6-3.8$ & $2.7-2.9$ & $20.56-21.92$ \\
Crystalline Crust 3 & $6.9-7.1$ & $3.9-3.9$ & $2.9-3.1$ & $30-32$ \\
\hline
\end{tabular}

Table 2

The Range of Layer Parameters Used for Vs Inversion in Western Java.

\begin{tabular}{|lllll|}
\hline Layer & P-wave $(\mathrm{km} / \mathrm{s})$ & S-wave $(\mathrm{km} / \mathrm{s})$ & Density $\left(\mathrm{g} / \mathrm{cm}^{3}\right)$ & Bottom Depth $(\mathrm{km})$ \\
\hline Sediment & $1.0-4.0$ & $0.5-2.5$ & 2.0 & $0.5-4.5$ \\
\hline Crystalline Crust 1 & $3.0-8.0$ & $2.0-3.5$ & 2.1 & $5.00-11.5$ \\
\hline Crystalline Crust 2 & $4.0-8.0$ & $2.8-4.0$ & 2.3 & $12.5-22.00$ \\
Crystalline Crust 3 & $6.0-8.0$ & $3.0-4.0$ & 2.6 & Half-space \\
\hline
\end{tabular}

We noted the range of values for the layer parameters $V p, V s$, and depth taken on by the Crust 1.0 model in western Java (Table 1), but found these ranges were too narrow to be used as the range of layer parameters in our inversion. We therefore chose the wider bounds on layer parameters indicated in Table 2, in order to allow for the inversion to explore models that were outside the range of Crust 1.0 model for western Java. In the inversion we assumed a fixed, uniform density in each layer of 2000 $\mathrm{kg} / \mathrm{m}^{3}, 2100 \mathrm{~kg} / \mathrm{m}^{3}, 2300 \mathrm{~kg} / \mathrm{m}^{3}$, and $2700 \mathrm{~kg} / \mathrm{m}^{3}$ for each layer, respectively. In this inversion, the relation of $V p$ and $V s$ is bounded by Poisson's ratio, ranging from 0.2 to 0.5 , which, together with the prior information of geological structure, may help limit parameter space to be searched.

Other parameters that should be considered are the two tuning parameters that control the behavior of the NA's exploitation (quick convergence of the misfit function) and exploration (investigation of nearly all local minima to find a global solution) of the model space. The parameters are the number of new models to sample at each iteration $\left(n_{s}\right)$ and the number of resampled Voronoi cells $\left(n_{r}\right)$. For the inversion 
parameters, we set the initial number of model samples $\left(\mathrm{n}_{s 0}\right)$ initially before starting the iteration to 200 , the $\mathrm{n}_{s}$ to 100 , and the $\mathrm{n}_{r}$ to 100 . Based on those parameterizations, we generate 50200 models. In this inversion, we set the maximum number of iterations to 500 .

\section{Results And Discussion}

\subsection{One Dimension Shear-wave Profile}

Results of inversion for selected 1D Vs profiles are shown in Fig. 3, with the location of each 1D Vs profile shown in Fig. 3a. Examples of dispersion curves and their associated Vs profiles are shown for Point 1 in the Banten area of westernmost Java, Point 2 in northern Java, and Point 3 in southern Java near the city of Garut (Figs. 3b, 3c and 3d, respectively). The misfit value at each of these points is less than 0.1, indicating the dispersion curve calculated from the optimum model is close to the observed curve. The best-fitting $V s$ models shown by the red curves are within the the confidence limits of the inversion result (shown by grayscale curves in Fig. 3b-d which represent the range of velocity for all models with misfit value $<0.2$ ). These estimated $V s$ profiles in Figs. $3 \mathrm{~b}-\mathrm{d}$ are compared with those of the Crust 1.0 model (green curves, from Laske et al, 2013).

Crust 1.0 includes an upper crustal sedimentary layer having $V s=0.88 \mathrm{~km} / \mathrm{s}$ that extends from the surface to $2 \mathrm{~km}$ depth throughout western Java. Our estimated $V s$ profiles also include a shallow, low- $V s$ layer, but $V s$ ranges from about $1 \mathrm{~km} / \mathrm{s}$ at the surface to about $2.5 \mathrm{~km} / \mathrm{s}$ at only $0.75 \mathrm{~km}$ depth. Hence, the gradient over the upper crustal sedimentary layer is much higher than that of Crust1.0. Instead of the rapid jump at about $2.5 \mathrm{~km}$ depth to a $V s>3 \mathrm{~km} / \mathrm{s}$ that characterize the transition from sedimentary to crystalline crustal layers in Crust1.0, our estimated $V s$ profiles increase more gradually from $2.5 \mathrm{~km} / \mathrm{s}$ at $0.75 \mathrm{~km}$ to higher velocities at mid-crustal depth. At Points 2 and 3 in the Banten and Garut areas, respectively, there appears to be a gradual increase to $\mathrm{Vs}>3 \mathrm{~km} / \mathrm{s}$ at about 9-10 km depth. In contrast, at Point 1 in the northern part of western Java, there is a weaker gradient in Vs from 0.75 to about $9 \mathrm{~km}$ depth, where there is a relatively sharp increase in velocity to $>3 \mathrm{~km} / \mathrm{s}$. Consequently, the average Vs in the uppermost $9 \mathrm{~km}$ of the crust is lower in the northeastern part of western Java than in the south or west.

\subsection{Pseudo-3D Vs Model}

A pseudo-3D upper crustal $V s$ map was produced by interpolating the 1-D profiles of the 557 grid points where dispersion curves were inverted. Plan views of the resulting $V s$ structure at selected depths between $0.5 \mathrm{~km}$ to $18 \mathrm{~km}$ can be seen in Fig. 4 . The orange color corresponds to $V s<2.75 \mathrm{~km} / \mathrm{s}$, which might be indicative of clastic rock of volcanic or sedimentary origin, while the blue color corresponds to $V s>2.75$ and is more indicative of a crystalline basement.

The Vs tomographic images in Fig. 4 reveal clear spatial patterns of high and low Vs anomalies that change with depth. At a depth of $0.5 \mathrm{~km}$, all of western Java is characterized by low $V s$, indicating the presence of quaternary sedimentary and volcanic deposits. At depth 1 to $5 \mathrm{~km}$, we observed a regional 
pattern with a striking NE-SW contrast of low vs. high $V s$. The northeastern half of western Java is characterized by low $V s$ with an average velocity of $\sim 2.25 \mathrm{~km} / \mathrm{s}$. In contrast, the southwestern half is characterized by high $V s$ of $\sim 2.75 \mathrm{~km} / \mathrm{s}$ or higher. The tomographic result for depth $1-5$ correlates well with the Bouguer gravity anomaly map from the Geological Survey of Indonesia (PSG) shown in Fig. 5a. Based on the Bouguer anomaly map, the northeastern part of western Java, which is characterized by low $V s$, exhibits a low Bouguer anomaly. The southwestern part of the western part of Java, characterized by high $V s$, has a high Bouguer anomaly. The boundary between these low and high $V s$ zones aligns remarkably well with the boundary between the low and high Bouguer anomaly (Fig. 5a vs. Figure 5b).

The low $V s$ of $2.25 \mathrm{~km} / \mathrm{s}$ in the depth range $1-5 \mathrm{~km}$ in the northeastern part of the study area, corresponding to the low Bouguer anomaly, is likely indicative of the same depositional products that fill the Northwest Java Basin that extends northward into the Java Sea: Eocene-Oligocene non-marine clastics, younger shallow shelf deposits, and late Tertiary and Quaternary volcanics (van Bemmelen 1949; Kingston 1988; Putra et al. 2016). A high $V s$ of $2.75 \mathrm{~km} / \mathrm{s}$ over depths $1-5 \mathrm{~km}$ coincides with high Bouguer anomaly in the southern and western parts of the study area. The high $V s$ in the south underlies the Southern Mountain Zone, a broad regional uplift formed of Eocene and Miocene rocks of old andesite formation and the Ciletuh, Jampang, and Bayah formations (van Bemmelen 1949; Parkinson et al. 1998; Hall et al. 2007). Clements et al. (2009) have shown that these are remnants of a submarine volcanic arc associated with subduction that began in the Eocene and were thrust northward by at least $50-100 \mathrm{~km}$ onto the southern edge of the Sunda Shelf. Because our ANT result and the Bouguer anomaly map show that both the high $V s$ and Bouguer gravity high extend much farther westward through all of then Banten area, we conjecture that this also reflects volcanic arc products of an earlier episode of subduction that now underlies all the westernmost part of Java -i.e., all of Banten as well as the Southern Mountains Zone.

The low velocity in the middle part of the study area are associated with depressions of the Bandung Zone, particularly the deep intermontane basins of Bandung and Garut, which are filled by coarse volcanoclastic, fluvial sediments, and a thick series of lacustrine deposits (van Bemmelen 1949; Dam et al. 1996). Low Vs in the Bandung Area was also found in the previous ANT study of Pranata et al. (2020), and interpreted to be associated with thick volcanoclastic deposits from Mt. Tangkuban Perahu and its massive predecessor, Mt. Sunda (see, Kartadinata et al. 2002, Nasution et al. 2004).

The Garut area, shown as a black dashed circle in (Fig. $5 b$ ), is associated with a low- $V s$ zone extending to at least $4 \mathrm{~km}$ depth, and is also in good agreement with the low Bouguer anomaly shown in Fig. $5 \mathrm{a}$. We suggest that the low Vs might be associated with two subsurface conditions. First, the Garut Basin is thought to have formed as a pull-apart basin, with extension creating a deep basin that is now filled with sediments and pyroclastic deposits. Second, two major active volcanoes, Mt. Guntur and Mt.

Papandayan, on the margin of the basin as well as geothermal activity show that there is abundant heat transfer and suggests the presence of deep and extensive hydrothermal and magmatic fluid systems (Fauzi et al. 2015). Both of these can account for the low $V s$ anomaly that extends to $5 \mathrm{~km}$ depth in the Garut area. 
For the deeper depth $\geq 6 \mathrm{~km}, V s$ gradually increases throughout western Java, especially in the Banten area and the southern mountain zone, which we surmise corresponds to the pre-tertiary metamorphic basement (van Bemmelen 1949; Hall et al. 2007; Clements et al. 2009; Putra et al. 2016). We also observed that $V s$ in this depth range beneath the active volcanoes in the Bandung and Garut areas is lower relative to its surroundings (Fig. 4). We suggest that the relatively low $V s$ there might include a signature of volcanic activity, such as high temperature and/or partial melt.

\subsection{Sedimentary Basin Geometry}

Thick sedimentary basin fill, characterized by low Vs and low Bouguer anomaly, is observed in the northern and central part of the study area. The northern part is associated with the Northwest Java Basin; meanwhile, the center area is associated with the depressions in the Bandung Zone, particularly the Garut Basin. We show a perspective view of vertical cross-sections in western Java in Fig. 6 , to illustrate the depth and the geometry of these basins. The vertical cross-section is passing-through the northern Java plain, Bandung, and Garut Basin. Figure 6 shows that the deepest sedimentary basin is in the northern area, in the onshore part of the Northwest Java Basin, which contains several depocenters dominantly filled with a Tertiary sequence with thickness in excess of $5.5 \mathrm{~km}$. Based on our cross-section, the northern basin has a depth of $\sim 5-7 \mathrm{~km}$, and we observed the basin is still thickening to the north, to the center of the Northwest Java Basin. In Fig. 6, we also observed a bowl-like feature beneath Garut, which we suggest is associated with Garut Basin with depth up to $\sim 5 \mathrm{~km}$.

\section{Conclusion}

We successfully inverted ambient noise data to obtain a 3-D shear wave velocity model of the upper crustal structure beneath the western part of Java at higher resolution than has been obtained from any previous study. From the Vs maps, we observe a NE-SW contrast of low and high Vs from the depth of 1$5 \mathrm{~km}$, which aligns with low and high anomalies in the Bouguer anomaly map. The low Vs in the northern and central parts (Bandung and Garut Basin) of the study area is associated with basin fill consisting of Eocene-Oligocene non-marine clastic deposits, products of late Tertiary and Quaternary volcanism, and late Quaternary fluvial and lacustrine sediments. The depth of the northern basin is in a range of 5-7 km, while the depth of the Garut Basin is up to $5 \mathrm{~km}$. At greater depths $\geq 6 \mathrm{~km}$, Vs gradually increases throughout western Java, which reflects the crystalline crustal basement underlying this area.

\section{Declarations}

\section{ACKNOWLEDGEMENTS}

We are grateful to the Australian National University (ANU grant 17MEC33) for providing the seismographs used in this study. We also would like to thank Vulcanology and Geothermal Laboratory members of Faculty of Mining and Petroleum Engineering, ITB for supporting the acquisition process and Geological Survey of Indonesia (PSG) for allowing the use of their Bouguer anomaly map. 
The data that support the findings of this study are available from the corresponding author, S. Rosalia, upon request.

\section{FUNDING}

This study was supported by "Riset P3MI ITB 2020" awarded to S. Widiyantoro and PMDSU scholarship granted to S. Rosalia from the Ministry of Research, Technology, and Higher Education of the Republic of Indonesia (2015-2019)

\section{AUTHORS' CONTRIBUTIONS}

S.Rosalia, S.Widiyantoro, P.Cummins., T.Yudistira., A.Dian Nugraha, Z.Zulfakriza contributing to the data processing, interpretation, and writing of the manuscript. A.Setiawan. contributed to the bouguer anomaly map. All authors contributed to the preparation of the manuscript. All authors have read and approved the final manuscript.

\section{COMPETING INTERESTS STATEMENT}

We declare that we have no known competing financial interests or personal relationships that could have appeared to influenced the work reported in this paper.

\section{References}

1. Aki K, Richards PG (2002) Quantitative Seismology, 2nd Ed

2. Ammon CJ, Kanamori H, Lay T, Velasco AA (2006) The 17 July 2006 Java tsunami earthquake. Geophys Res Lett 33:1-5. https://doi.org/10.1029/2006GL028005

3. Anggono T, Syuhada S, Febriani F et al (2020) Crustal shear-wave velocity structure in Western Java, Indonesia from analysis of teleseismic receiver functions. J Earth Syst Sci 129:. https://doi.org/10.1007/s12040-019-1288-1

4. Bache TC, Rodi WL, Harkrider DG (1978) Crustal structures inferred from Rayleigh-wave signatures of NTS explosions. Bull Seismol Soc Am 68:1399-1413

5. Cipta A, Cummins P, Dettmer J et al (2018a) Seismic velocity structure of the Jakarta Basin, Indonesia, using trans-dimensional Bayesian inversion of horizontal-to-vertical spectral ratios. Geophys J Int 215:431-449. https://doi.org/10.1093/gji/ggy289

6. Cipta A, Cummins P, Irsyam M, Hidayati S (2018b) Basin resonance and seismic hazard in jakarta. Indonesia Geosci 8:1-25. https://doi.org/10.3390/geosciences8040128

7. Clements B, Hall R, Smyth HR, Cottam MA (2009) Thrusting of a volcanic arc: A new structural model for Java. Pet Geosci 15:159-174. https://doi.org/10.1144/1354-079309-831 
8. Dam MAC, Suparan P, Nossin JJ et al (1996) A chronology for geomorphological developments in the greater Bandung area, West-Java, Indonesia. J Southeast Asian Earth Sci 14:101-115. https://doi.org/10.1016/S0743-9547(96)00069-4

9. Fauzi A, Permana H, Indarto S, Gaffar EZ (2015) Regional Structure Control on Geothermal Systems in West Java, Indonesia

10. Fujii Y, Satake K (2006) Source of the July 2006 West Java tsunami estimated from tide gauge records. Geophys Res Lett 33:2-6. https://doi.org/10.1029/2006GL028049

11. Gunawan E, Widiyantoro S, Marliyani GI et al (2019) Fault source of the 2 September 2009 Mw 6.8 Tasikmalaya intraslab earthquake, Indonesia: Analysis from GPS data inversion, tsunami height simulation, and stress transfer. Phys Earth Planet Inter 291:54-61. https://doi.org/10.1016/j.pepi.2019.04.004

12. Griffin J, Nguyen N, Cummins P, Cipta A (2019) Historical earthquakes of the eastern sunda arc: Source mechanisms and intensity-based testing of Indonesia's national seismic hazard assessment. Bull Seismol Soc Am 109:43-65. https://doi.org/10.1785/0120180085

13. Hall R, Clements B, Smyth HR, Cottam MA (2007) A NEW INTERPRETATION OF JAVA'S STRUCTURE

14. Hamilton WB (1979) Tectonics of the Indonesian region

15. Hawkins R, Sambridge M (2015) Geophysical imaging using trans-dimensional trees. Geophys J Int 203(2):972-1000. http://doi.org/10.1093/gji/ggv326

16. Hayes GP, Moore GL, Portner DE et al (2018) Slab2, a comprehensive subduction zone geometry model. Science 362:58-61. https://doi.org/10.1126/science.aat4723

17. Irsyam M, Cummins PR, Asrurifak M et al (2020) Development of the 2017 national seismic hazard maps of Indonesia. Earthq Spectra 36:112-136. https://doi.org/10.1177/8755293020951206

18. Kartadinata MN, Okuno M, Nakamura T, Kobayashi T (2002) Eruptive History of Tangkuban Perahu

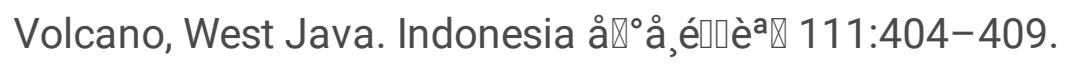
https://doi.org/10.5026/jgeography.111.3_404

19. Kingston J (1988) Undiscovered petroleum resources of Indonesia

20. Koulali A, McClusky S, Susilo S et al (2017) The kinematics of crustal deformation in Java from GPS observations: Implications for fault slip partitioning. Earth Planet Sci Lett 458:69-79. https://doi.org/10.1016/j.epsl.2016.10.039

21. Laske G, Masters G, Ma Z, Pasyanos M (2013) Update on CRUST1. 0-A 1-degree global model of Earth's crust. In: Geophys. Res. Abstr. p 2658

22. Lobkis Ol, Weaver RL (2001) On the emergence of the Green's function in the correlations of a diffuse field. J Acoust Soc Am 110:3011-3017. https://doi.org/10.1121/1.1417528

23. Malod JA, Karta K, Beslier MO, Zen MT (1995) From normal to oblique subduction: Tectonic relationships between Java and Sumatra. J Southeast Asian Earth Sci 12:85-93. https://doi.org/10.1016/0743-9547(95)00023-2 
24. Martha AA, Cummins P, Saygin E et al (2017) Imaging of upper crustal structure beneath East JavaBali, Indonesia with ambient noise tomography. Geosci Lett 4:. https://doi.org/10.1186/s40562-0170080-9

25. Nasution A, Kartabinata MN, Sutamingsih E et al (2004) Geology, Age Dating and Geochemistry of the Tangkuban Parahu Geothermal Area, West Java, Indonesia. J Geotherm Res Soc Japan 26:285303. https://doi.org/10.11367/grsj1979.26.285

26. Nishida K (2017) Ambient seismic wave field. Proc. Japan Acad. Ser. B Phys. Biol. Sci. 93:423-448

27. Parkinson CD, Miyazaki K, Wakita K et al (1998) An overview and tectonic synthesis of the preTertiary very-high-pressure metamorphic and associated rocks of Java, Sulawesi and Kalimantan, Indonesia. Isl Arc 7:184-200. https://doi.org/10.1046/j.1440-1738.1998.00184.x

28. Porritt RW, Miller MS, O'Driscoll LJ et al (2016) Continent-arc collision in the Banda Arc imaged by ambient noise tomography. Earth Planet Sci Lett 449:246-258.

https://doi.org/10.1016/j.epsl.2016.06.011

29. Pranata B, Yudistira T, Saygin E et al (2018) Seismic microzonation of Bandung basin from microtremor horizontal-to-vertical spectral ratios (HVSR). AIP Conf Proc 1987: https://doi.org/10.1063/1.5047289

30. Pranata B, Yudistira T, Widiyantoro $S$ et al (2020) Shear wave velocity structure beneath Bandung basin, West Java, Indonesia from ambient noise tomography. Geophys J Int 220:1045-1054. https://doi.org/10.1093/gji/ggz493

31. Putra SDH, Suryantini, Srigutomo W (2016) Thermal modeling and heat flow density interpretation of the onshore Northwest Java Basin, Indonesia. Geotherm Energy 4.. https://doi.org/10.1186/s40517016-0052-x

32. Ridwan M, Cummins PR, Widiyantoro S, Irsyam M (2019) Site characterization using microtremor array and seismic hazard assessment for Jakarta, Indonesia. Bull Seismol Soc Am 109:2644-2657. https://doi.org/10.1785/0120190040

33. Ridwan M, Widiyantoro S, Irsyam M et al (2017) Development of an engineering bedrock map beneath Jakarta based on microtremor array measurements. Geol Soc Spec Publ 441:153-165. https://doi.org/10.1144/SP441.7

34. Rosalia S, Cummins P, Widiyantoro $S$ et al (2020) Group velocity maps using subspace and transdimensional inversions: Ambient noise tomography in the western part of Java, Indonesia. Geophys J Int 220:1260-1274. https://doi.org/10.1093/gji/ggz498

35. Rosalia S, Widiyantoro S, Dian Nugraha A et al (2019) Double-difference tomography of P-and Swave velocity structure beneath the western part of Java, Indonesia. Earthq Sci 32:12-25. https://doi.org/10.29382/eqs-2019-0012-2

36. Ryberg T, Muksin U, Bauer K (2016) Ambient seismic noise tomography reveals a hidden caldera and its relation to the Tarutung pull-apart basin at the Sumatran Fault Zone, Indonesia. J Volcanol Geotherm Res 321:73-84. https://doi.org/10.1016/j.jvolgeores.2016.04.035 
37. Sambridge M (1999a) Geophysical inversion with a neighbourhood algorithm - I. Searching a parameter space. Geophys J Int 138:479-494. https://doi.org/10.1046/j.1365-246X.1999.00876.x

38. Sambridge M (1999b) Geophysical inversion with a neighbourhood algorithm: II. Appraising the ensemble. Geophys J Int 138:727-746. https://doi.org/10.1046/j.1365-246x.1999.00900.x

39. Saygin E, Cummins PR, Cipta A et al (2016) Imaging architecture of the Jakarta Basin, Indonesia with transdimensional inversion of seismic noise. Geophys J Int 204:918-931.

https://doi.org/10.1093/gji/ggv466

40. Shapiro NM, Campillo M (2004) Emergence of broadband Rayleigh waves from correlations of the ambient seismic noise. Geophys Res Lett 31:. https://doi.org/10.1029/2004GL019491

41. Sirait AMM, Meltzer AS, Waldhauser F et al (2020) Analysis of the 15 December $2017 \mathrm{Mw} 6.5$ and the 23 January 2018 Mw 5.9 Java Earthquakes. Bull Seismol Soc Am. https://doi.org/10.1785/0120200046

42. Snieder R, Wapenaar K (2010) Imaging with ambient noise. Phys Today 63:44-49. https://doi.org/10.1063/1.3490500

43. Spica Z, Caudron C, Perton M et al (2015) Velocity models and site effects at Kawah ljen volcano and ljen caldera (Indonesia) determined from ambient noise cross-correlations and directional energy density spectral ratios. J Volcanol Geotherm Res 302:173-189.

https://doi.org/10.1016/j.jvolgeores.2015.06.016

44. Stankiewicz J, Ryberg T, Haberland C et al (2010) Lake Toba volcano magma chamber imaged by ambient seismic noise tomography. Geophys Res Lett 37:3-7.

https://doi.org/10.1029/2010GL044211

45. Suardi I, Afnimar S, Yagi Y others (2014) Moment tensor analysis of the September 2, 2009 Tasikmalaya, West Java earthquake using the waveform inversion method of near field data. Int $\mathrm{J}$ Tomogr Simul 63-74

46. Takeuchi H, Saito M (1972) Seismic surface waves. Methods Comput Phys 11:217-295

47. Tanimoto $T$ (1991) Waveform inversion for three-dimensional density and $S$ wave structure. $J$ Geophys Res Solid Earth 96:8167-8189. https://doi.org/https://doi.org/10.1029/91JB00196

48. van Bemmelen RW (1949) The geology of Indonesia. 1, A. General geology of Indonesia and adjacent archipelagoes. US Government Printing Office

49. Wathelet M (2008) An improved neighborhood algorithm: Parameter conditions and dynamic scaling. Geophys Res Lett 35:. https://doi.org/10.1029/2008GL033256

50. Wathelet M, Jongmans D, Ohrnberger M (2004) Surface-wave inversion using a direct search algorithm and its application to ambient vibration measurements. Near Surf Geophys 2:211-221. https://doi.org/10.3997/1873-0604.2004018

51. Widiyantoro S, Gunawan E, Muhari A et al (2020) Implications for megathrust earthquakes and tsunamis from seismic gaps south of Java Indonesia. Sci Rep 10:. https://doi.org/10.1038/s41598020-72142-z 
52. Widiyantoro S, Pesicek JD, Thurber $\mathrm{CH}$ (2011) Subducting slab structure below the eastern Sunda arc inferred from non-linear seismic tomographic imaging. Geol Soc Spec Publ 355:139-155. https://doi.org/10.1144/SP355.7

53. Widiyantoro S, Van Der Hilst R (1996) Structure and evolution of lithospheric slab beneath the Sunda arc, Indonesia. Science 271:1566-1570. https://doi.org/10.1126/science.271.5255.1566

54. Zulfakriza Z, Nugraha AD, Widiyantoro $S$ et al (2020) Tomographic Imaging of the Agung-Batur Volcano Complex, Bali, Indonesia, From the Ambient Seismic Noise Field. Front Earth Sci 8:1-11. https://doi.org/10.3389/feart.2020.00043

55. Zulfakriza Z, Saygin E, Cummins PR et al (2014) Upper crustal structure of central Java, Indonesia, from transdimensional seismic ambient noise tomography. Geophys J Int 197:630-635. https://doi.org/10.1093/gji/ggu016

\section{Figures}



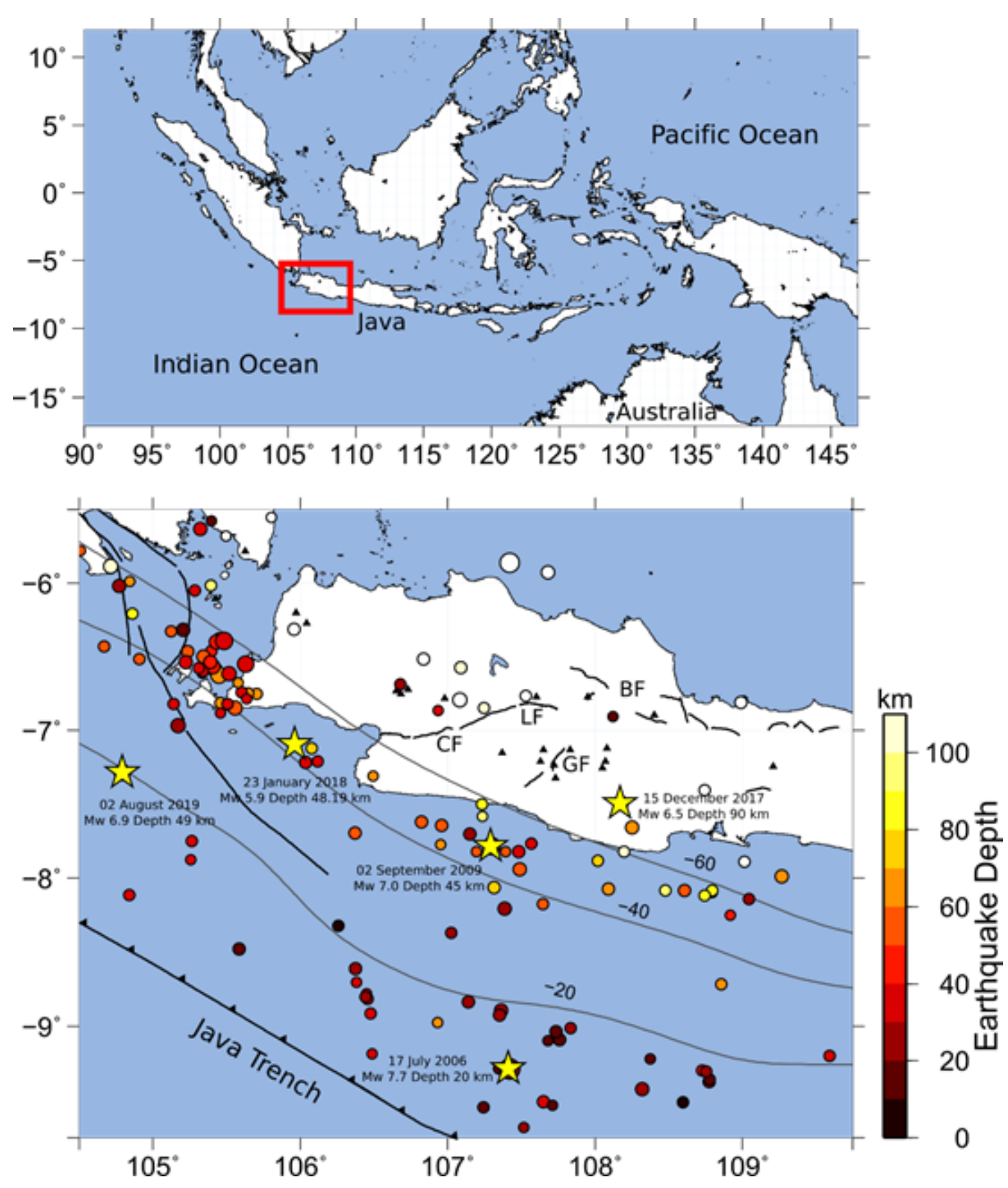

Figure 1

Map showing the historical seismicity and major fault in the western part of Java. The colored circles show the seismicity from the USGS catalog for events with $M w \geq 5.5$. The yellow star represents the major earthquakes in which the shaking could be felt in the major cities of West Java. The black lines denoted three major faults: Cimandiri Fault (CF), Lembang Fault (LF), Baribis Fault (BF), and Garsela Fault (GF). The fault is plotted from Pusat Studi Gempa Nasional (PuSGen) 2017 (see, Irsyam et al., 2020). Black triangles are active volcanoes, and gray lines are the slab2 contour (Hayes et al. 2018) Note: The designations employed and the presentation of the material on this map do not imply the expression of any opinion whatsoever on the part of Research Square concerning the legal status of any country, territory, city or area or of its authorities, or concerning the delimitation of its frontiers or boundaries. This map has been provided by the authors. 


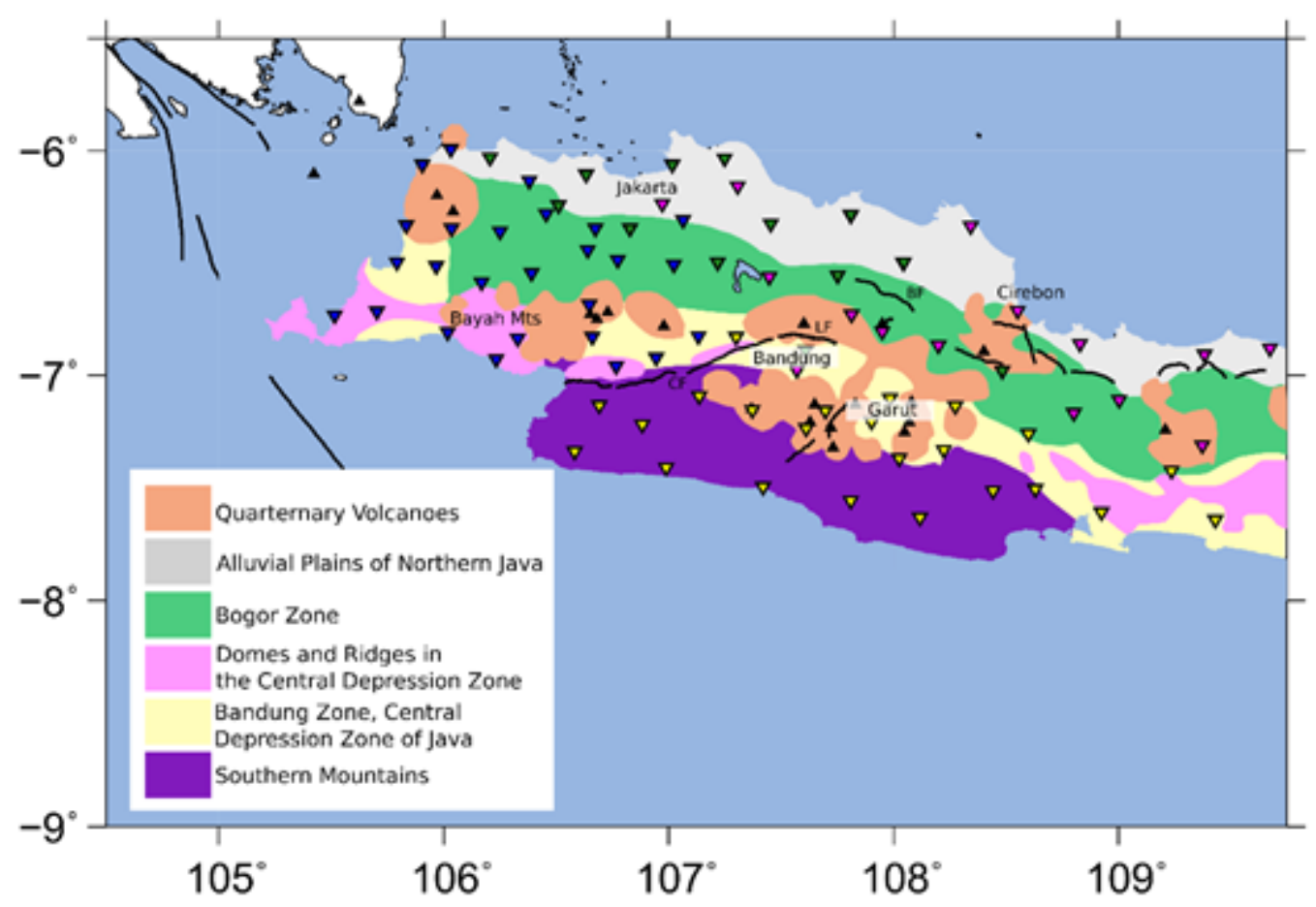

Figure 2

Map showing the physiography (van Bemmelen 1949) and station distribution in the western part of Java. The black lines denoted faults from Pusat Studi Gempa Nasional (PuSGen) 2017 (see, Irsyam et al., 2020). Black triangles are active volcanoes, and inverted triangles are the station with color showing the area and period of the deployment. Blue, yellow, magenta, and green color represent the seismometers deployed in Banten, the southern part of the study area, the northern part of the study area in 2016, and the northern part of the study area in 2018, respectively. Note: The designations employed and the presentation of the material on this map do not imply the expression of any opinion whatsoever on the part of Research Square concerning the legal status of any country, territory, city or area or of its authorities, or concerning the delimitation of its frontiers or boundaries. This map has been provided by the authors. 
(a)

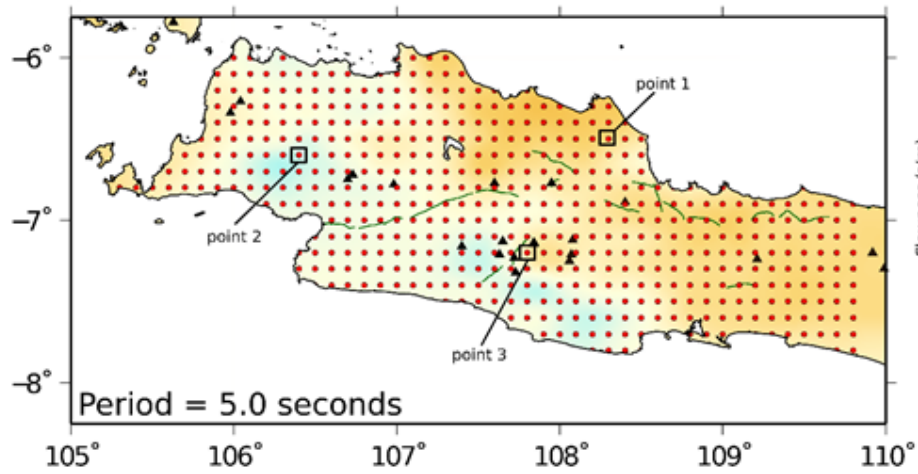

(c) Point 2: Longitude $106.4^{\circ}$ Latitude $6.6^{\circ}$

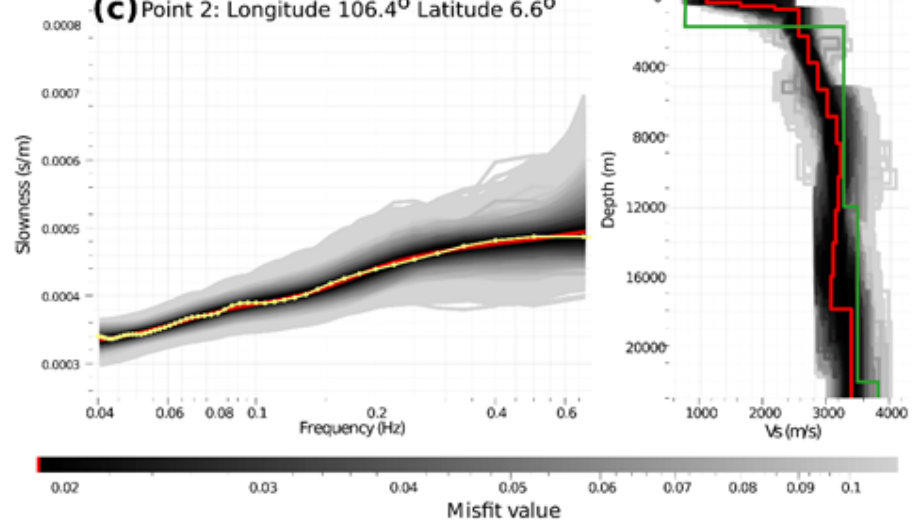

(b) Point 1: Longitude $108.3^{\circ}$ Latitude $6.6^{\circ}$

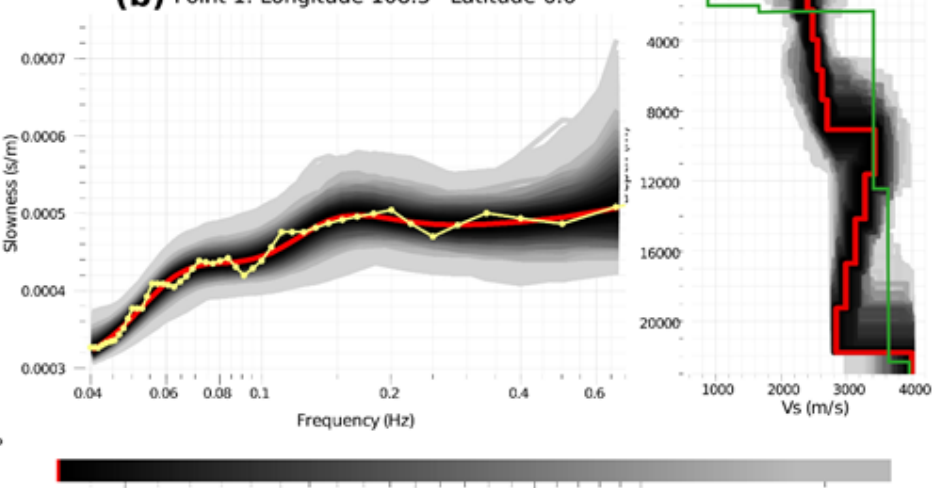

(d) Point 3: Longitude $107.8^{\circ}$ Latitude $7.2^{\circ}$

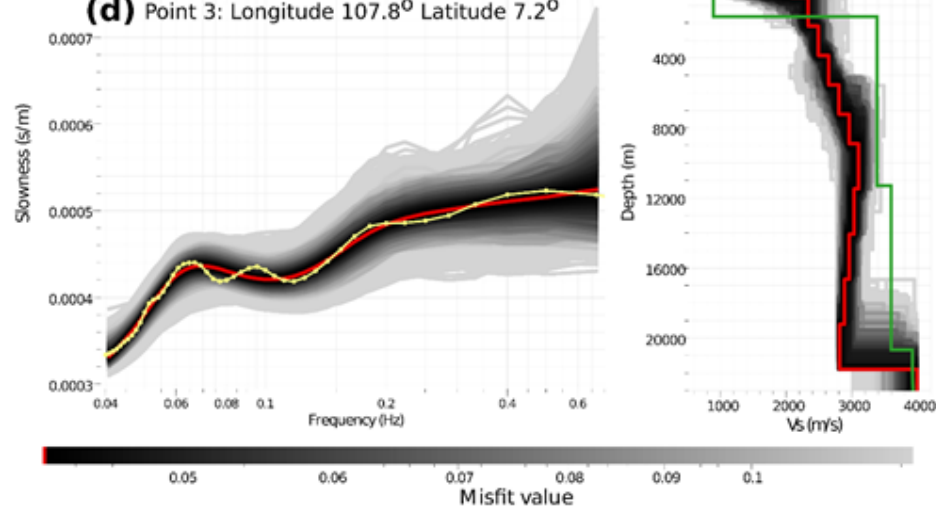

Figure 3

a) The grid locations (red dots) where dispersion curves are extracted from group velocity maps and inverted for Vs depth profiles. There are 557 points in total, with a distance between points of 0.10 . The background map is the group velocity result for period $5.0 \mathrm{~s}$ from trans-dimensional tree inversion (Rosalia et al. 2020). b-d) Examples of 1D depth profile inversions using the dinver package of Geopsy at points 1,2,3 shown in (a), respectively. The yellow line in the dispersion curve represents the observed data, and the red line in the dispersion curve represents the calculated model. The red line in the 1D velocity model shows the optimum velocity model. The black to gray lines in both the dispersion curves and 1D profiles represent the generated ensemble models with their corresponding misfit values. The green line shows the velocity from CRUST1.0 (Laske et al. 2013). Note: The designations employed and the presentation of the material on this map do not imply the expression of any opinion whatsoever on the part of Research Square concerning the legal status of any country, territory, city or area or of its authorities, or concerning the delimitation of its frontiers or boundaries. This map has been provided by the authors. 

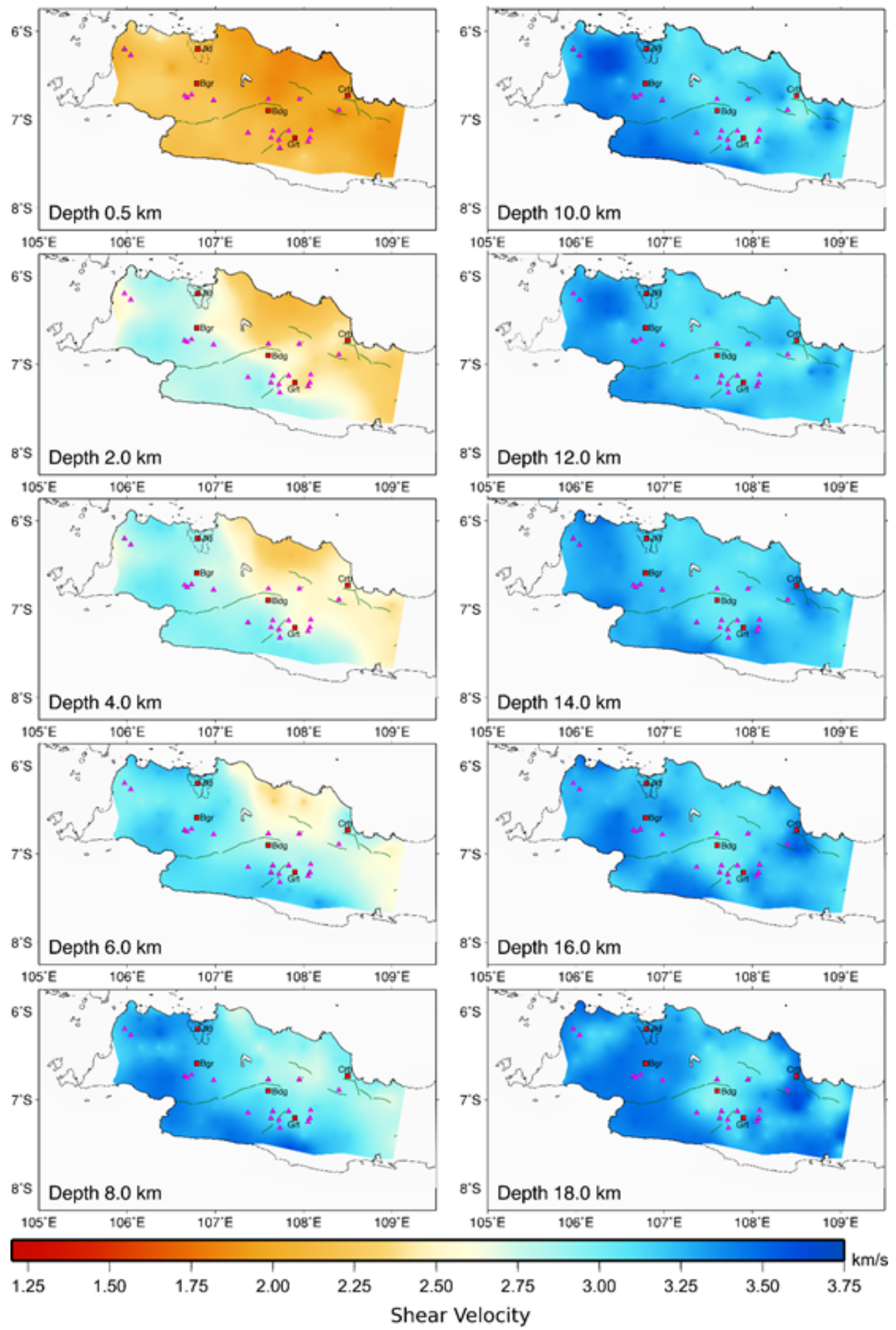

Figure 4

The shear-wave velocity maps of the western part of Java from depth $0.5-18 \mathrm{~km}$. The green curves are faults and the magenta triangles are volcanoes. The white colored areas are those with poor raypath coverage. Jkt, Bgr, Crb, Bdg, and Grt stand for the cities of Jakarta, Bogor, Cirebon, Bandung, and Garut, respectively. Note: The designations employed and the presentation of the material on this map do not imply the expression of any opinion whatsoever on the part of Research Square concerning the legal 
status of any country, territory, city or area or of its authorities, or concerning the delimitation of its frontiers or boundaries. This map has been provided by the authors.
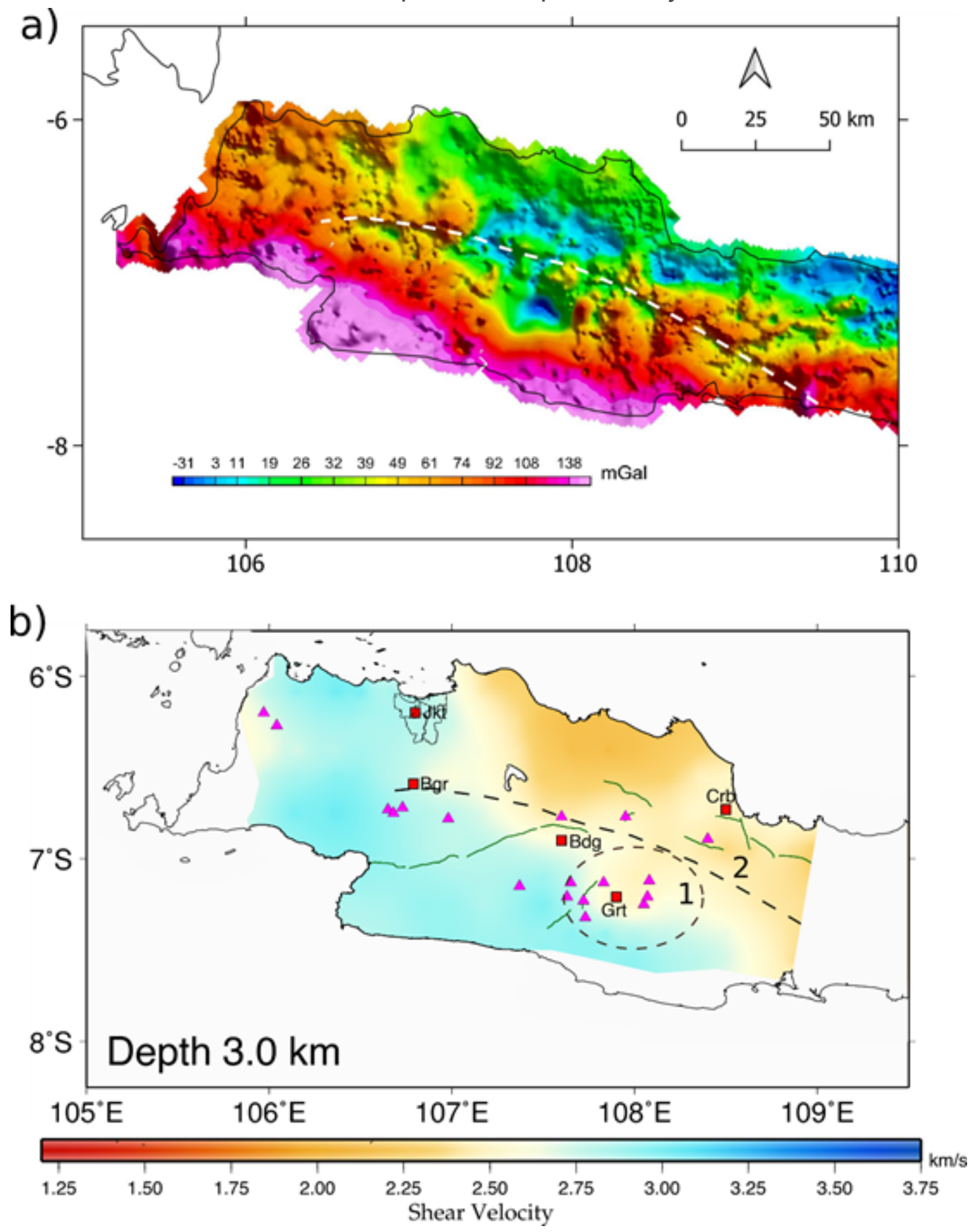

Figure 5

a) Bouguer anomaly map of western part of Java from Geological Survey of Indonesia (PSG). The white dashed line is the major structure delineated from the relief lineaments (Fauzi et al., 2015), b) Vs maps from depth $3 \mathrm{~km}$. Number 1 denoted the Garut Circular Feature and number 2 denoted the major structure line from Bouguer Anomaly in a). Note: The designations employed and the presentation of the material on this map do not imply the expression of any opinion whatsoever on the part of Research Square 
concerning the legal status of any country, territory, city or area or of its authorities, or concerning the delimitation of its frontiers or boundaries. This map has been provided by the authors.

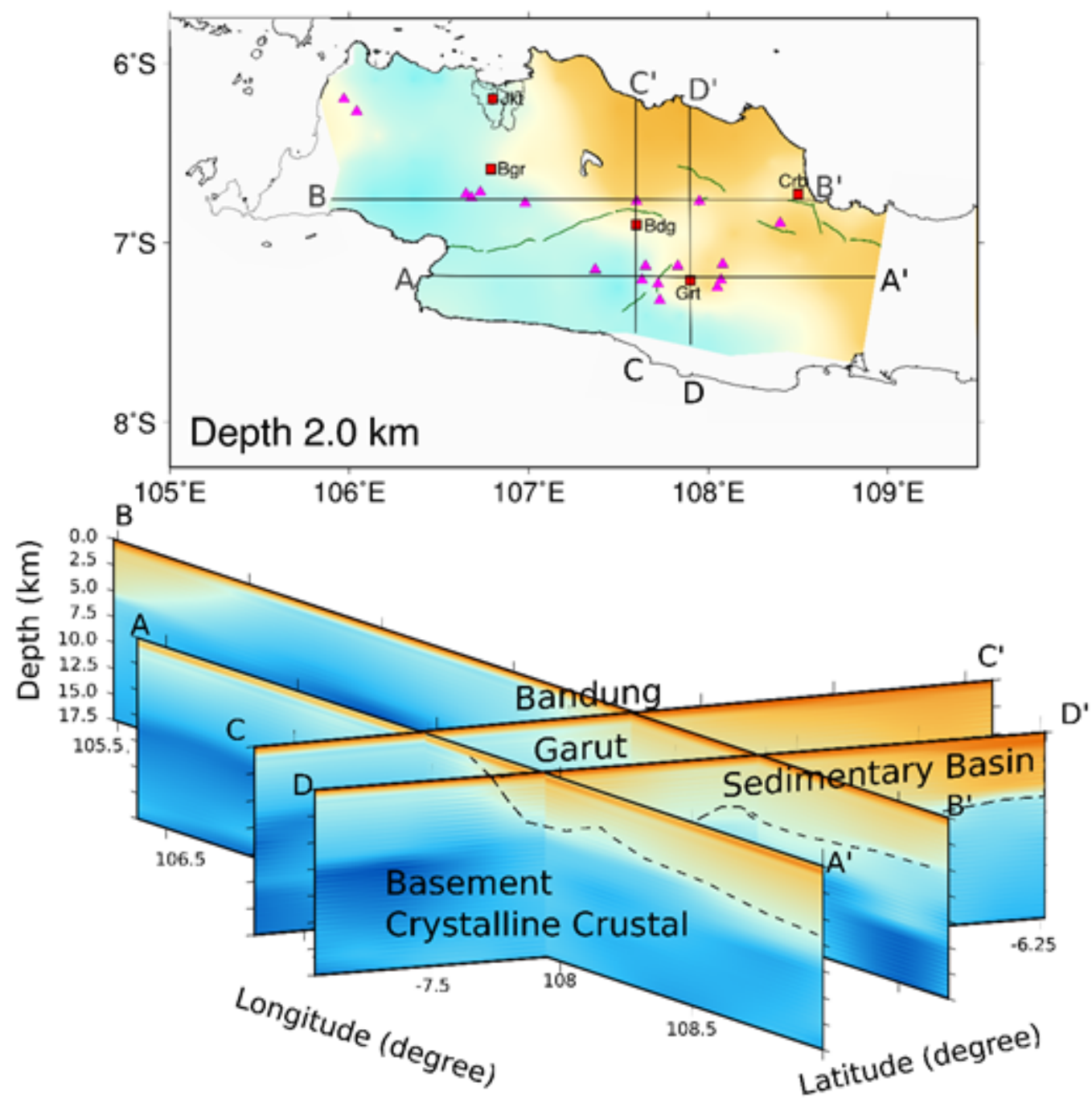

Figure 6

Cross-section of Vs model beneath the western part of Java. The low velocity associated with sedimentary deposit in the northern, Bandung, and Garut Basin, as well as the high velocity associated with the metamorphic and igneous crystalline crust are clearly evident. Note: The designations employed and the presentation of the material on this map do not imply the expression of any opinion whatsoever on the part of Research Square concerning the legal status of any country, territory, city or area or of its authorities, or concerning the delimitation of its frontiers or boundaries. This map has been provided by the authors. 